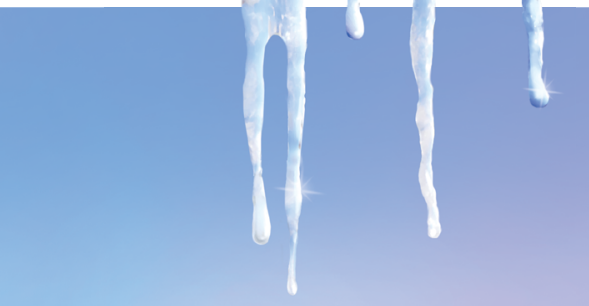

Oliver C. Ruppel I Christian Roschmann I Katharina Ruppel-Schlichting

\title{
Climate Change: International Law and Global Governance
}

Volume II: Policy, Diplomacy and Governance in a Changing Environment

\section{Nomos}


https://doi.org/10.5771/9783845242774_?

Generiert durch IP '172.22.53.54', am 26.04.2023, 13:52:08.

Das Erstellen und Weitergeben von Kopien dieses PDFs ist nicht zulässig. 
Prof. Dr. Oliver C. Ruppel |

Prof. Dr. Christian Roschmann |

Dr. Katharina Ruppel-Schlichting [Eds]

\section{Climate Change:}

International Law and Global Governance

Volume II: Policy, Diplomacy and Governance in a Changing Environment 


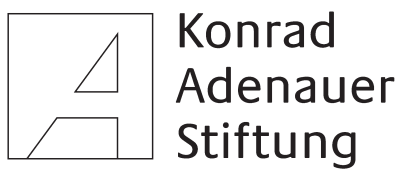

Die Deutsche Nationalbibliothek lists this publication in the Deutsche Nationalbibliografie; detailed bibliographic data is available in the Internet at http://dnb.d-nb.de.

ISBN 978-3-8329-7796-2

Language Editing: Julie Streicher \& The Word Factory

The content of the articles, including any final errors or omissions that remain, is the sole responsibility of the individual contributors. The editors have made every effort to acknowledge the use of copyright material. Should any infringement of copyright have occurred, please contact the editors, and every effort will be made to rectify omissions or errors, in the event of a reprint or new edition.

1. Edition 2013

(C) Nomos Verlagsgesellschaft, Baden-Baden 2013. Printed in Germany.

This work is subject to copyright. All rights are reserved, whether the whole or part of the material is concerned, specifically those of translation, reprinting, re-use of illustrations, broadcasting, reproduction by photocopying machine or similar means, and storage in data banks. Under $\S 54$ of the German Copyright Law where copies are made for other than private use a fee is payable to "Verwertungsgesellschaft Wort", Munich. 
Contents

FOREWORD 9

$\begin{array}{ll}\text { PREFACE } & 11\end{array}$

ACKNOWLEDGEMENTS 13

THE EDITORS 15

$\begin{array}{ll}\text { THE CONTRIBUTORS } & 17\end{array}$

\section{PART I: GLOBAL CLIMATE GOVERNANCE -} DEVELOPMENTS AND CHALLENGES

1 Intersections of Law and Cooperative Global Climate Governance - Challenges in the Anthropocene

Oliver C. Ruppel

2 International Climate Change Policy: Where do we Stand?

Nadia von Bassewitz

3 Climate Change Lawfare

Siri Gloppen \& Asuncion Lera St. Clair

4 Greening Permanent Sovereignty through the Common Concern in the Climate Change Regime: Awake Custodial Sovereignty! 201 Werner Scholtz

\section{PART II: GLOBAL CLIMATE GOVERNANCE AND DIPLOMACY}

5 Power in Global Climate Governance Babette Never

6 CBDR as a Principle of Inspiring Actions rather than Justifying Inaction in the Global Climate Change Regime

Achala C. Abeysinghe \& Gilberto Arias 
7 Beyond International Climate Negotiations: Climate Diplomacy from a Foreign Policy Perspective

Dennis Tänzler \& Alexander Carius

8 Confronting Complex Global Challenges: Comparing the Climate Change and Law of the Sea Negotiations Gregg B. Walker

9 UNEP plus X? A Critical Assessment of Reform: Proposals and Implications for the International Climate Regime

Dirk Hanschel

\section{PART III: A TRANSDISCIPLINARY MIX: CLIMATE CHANGE, POLITICS AND FINANCE}

10 Transdisciplinarity: Theory and Visions on Global

Transdisciplinary Processes for Adapting to Climate Change

Roland W. Scholz

11 The Politics of Climate Change: Review and Future Challenges

Holger Haibach \& Kathrin Schneider

12 International Climate Finance: Policies, Structures and

Challenges

Cord Lüdemann \& Oliver C. Ruppel

\section{PART IV: CLIMATE CHANGE POLICY, COOPERATION AND PROTECTION EFFORTS}

13 Climate Change Law and Policy Positions in the African Union and Related Developments in Selected African Countries

Oliver C. Ruppel

14 Council of Europe Climate Law Standards and Perspectives Agata Rogalska-Piechota

15 Renewable Energy Policy in the European Union: A Contribution to Meeting International Climate Protection Goals?

Christian Calliess \& Christian Hey 
16 China-Africa Cooperation: Joint Engagement in Adaptation to Climate Change

Wanxin Li, Sven Grimm \& Harrie Esterhuyse

17 The BRICS Partnership: Development and Climate Change Policy from an African Perspective

Oliver C. Ruppel \& Katharina Ruppel-Schlichting

\section{PART V: CLIMATE CHANGE RESPONSES, EQUITY AND SUSTAINABLE DEVELOPMENT}

18 Sustainable and Inclusive Adaptation to Climate Change and Public Policy Challenges in Central America

Julie G. Lennox

19 Mainstreaming Sustainable Development into National Climate Change Responses: Assessing the Legal Options to Reinforce Equity

Robert Kibugi

20 Agenda 21 and Climate Protection: The Development of Global and Local Governance for Environment and Development Observations from Research in Namibia Manfred O. Hinz

21 Ethics for Climate Justice and Sustainability through Value-based Approaches: A New Tanzanian Model and Paradigm Shift Aidan G. Msafiri

\section{PART VI: CLIMATE CHANGE, SECURITY AND THE MIGRATION DEBATE}

22 Science, Facts and Fears: The Debate on Climate Change and Security

Marcel Leroy \& Fana Gebresenbet

23 Dangerous Anthropogenic Climate Change from the Perspective of Adaptation

Kristie L. Ebi \& Ian Burton 
24 Climate Change, Disasters and Migration: Current Challenges to International Law

Erika Pires Ramos

25 Enhancing Adaptation Options and Managing Human Mobility in the Context of Climate Change: Role of the United Nations

Framework Convention on Climate Change

Koko Warner

26 Adaptation to Climate Change under Changing Urban Patterns:

The Climatic Perspective of Migration

María Máñez Costa, Kathleen Schwerdtner Máñez \& Sainab

Husain Paragay

27 Climate-change-induced Movement of Persons in Africa: Human Rights Responses to Aspects of Human Security

Oliver C. Ruppel \& Sanita van Wyk

\section{PART VII:CLIMATE CHANGE AND THE LOSS AND DAMAGE DEBATE}

28 Framing the Loss and Damage Debate: A Thought Starter by the Loss and Damage in Vulnerable Countries Initiative

Sönke Kreft, Koko Warner, Sven Harmeling \& Erin Roberts

29 Legal and Policy Responses to Loss and Damage Associated with Climate Change

M. Hafijul Islam Khan

30 Insurance Solutions in the Context of Climate-Change-Related Loss and Damage: Needs, Gaps and Roles of the UNFCCC in Addressing Loss and Damage Koko Warner, Sönke Kreft, Michael Zissener, Peter Höppe, Christoph Bals, Thomas Loster, Joanne Linnerooth-Bayer, Silvio Tschudi, Eugene Gurenko, Armin Haas, Simon Young, Paul Kovacs, Andrew Dlugolecki \& Aaron Oxley

Annex

Contents Volume I

Climate Change: International Law and Global Governance

Volume I: Legal Responses and Global Responsibility 